\title{
The Role of Th17 Cells in the Pathogenesis of Behcet's Disease
}

\author{
Yuki Nanke *, Toru Yago (iD and Shigeru Kotake \\ Institute of Rheumatology, Tokyo Women's Medical University, 10-22 Kawada-cho, Shinjuku-ku, \\ Tokyo 162-0054, Japan; toruyago@twmu.ac.jp (T.Y.); skotake@twmu.ac.jp (S.K.) \\ * Correspondence: ynn@twmu.ac.jp; Tel.: +81-3-5269-1725; Fax: +81-3-5269-1726 \\ Academic Editor: Emmanuel Andrès \\ Received: 27 April 2017; Accepted: 12 July 2017; Published: 21 July 2017
}

\begin{abstract}
Behcet's disease (BD) is a polysymptomatic and recurrent systemic vasculitis with a chronic course and unknown cause. The pathogenesis of BD has not been fully elucidated; however, BD has been considered to be a typical Th1-mediated inflammatory disease, characterized by elevated levels of Th1 cytokines such as IFN- $\gamma$, IL-2, and TNF- $\alpha$. Recently, some studies reported that Th17-associated cytokines were increased in BD; thus, Th17 cells and the IL17/IL23 pathway may play important roles in the pathogenesis of BD. In this chapter, we focus on the pathogenic role of Th17 cells in BD.
\end{abstract}

Keywords: Behcet's disease; IL-17; Th17; regulatory T cells; Th1

\section{Introduction}

Behcet's disease (BD) is a polysymptomatic and recurrent systemic vasculitis with a chronic course and unknown cause [1]. BD is characterized by recurrent aphthous stomatitis, uveitis, genital ulcers, and skin lesions. Arthritis is also a common manifestation of BD, and sometimes inflammation is involved in the gastrointestinal tract as well as vascular and central nervous systems. The HLA-B51 gene is closely associated with BD in different ethnic groups. Resent genome-wide studies showed the association of several non-histocompatibility complex (MHC) genes, including IL-10 and IL-23R-IL12 RB 2 genes [2,3]. The pathogenesis of BD is still unclear; in addition to genetic factors, immune dysfunction, and cytokines, viral, and bacterial agents are associated with the exacerbation of the disease. In BD, CD4+ T cells and neutrophils play an essential role in the pathogenesis of the disease. Since IFN- $\gamma$ and IL-12 from Th1 cells can mediate the inflammatory response between T cells and neutrophils, BD has historically been regarded as a Th1- mediated disease [4,5]. Th17 cells are a novel $\mathrm{T}$ cell population that play a major role in autoimmunity. Th17 cell differentiation from naïve CD4+ $\mathrm{T}$ cells is facilitated by some cytokines, including IL-1 $\beta$, IL-6, IL-21, and IL-23. The critical feature of Th17 cells is the expression of Il-17A, IL-17F, IL-6, IL-8, TNF- $\alpha$, Il-22, IL-26, and the expression of RAR-related orphan receptor (ROR) $\gamma$. Recently, the immunopathological effects of Th17 cells in the development of BD were reported. Since IL-17 has been shown to selectively recruit neutrophils to the site of inflammation, abnormalities in the $\mathrm{T}$ cell response result in the hyper-reactivity of neutrophils in BD through the production of cytokines such as IL-17 [6]. We review the pathogenic role of Th17 cells in BD in this chapter.

\section{Th-17 in Mouse Model}

In mice, the combination of TGF- $\beta$ and IL-6 plays an important role in the development of Th17 cells from naïve T cells. Th17 cells and IL-17 play critical roles in the pathogenesis of intraocular inflammation in an animal model of human uveitis [7-9]. Anti-mouse IL-17-blocking antibodies suppress intraocular inflammation in experimental uveitis models [10]. 
The down-regulation of IL-6 [11] and inhibition of the expression of TNF- $\alpha$ [12] improved the inflammatory symptoms in BD mice through the up-regulation of Th17 cells. Foxp3 has been speculated to inhibit Th17 differentiation by antagonizing the function of ROR $\gamma \mathrm{t}$, the master transcription factor (mice). Sugita et al. showed that anti-TNF- $\alpha$ blockade may prevent the differentiation of Th17 cells in animal models for BD [13]. $\gamma \delta$ T cells have also been shown to produce IL-17 and may play a crucial role in experimental uveitis in animal models [9].

\section{Th17 in Humans}

\subsection{Plasma IL-17 Levels in BD}

In humans, IL-1 $\beta$ and IL-23 are required for the development of Th17 cells. Some investigators [14-16] reported the ability to produce IL-17A and the percentage of circulating Th17 cells were increased in patients with active BD. Hamzaoui et al. also demonstrated that both the population of Th17 cells and the ability to produce IL-17A were enhanced in active BD, despite the low expression of ROR $\gamma \mathrm{t}$ mRNA [14].

\subsection{Increased Circulating Th17 Cell Frequencies are Correlated with Disease Activity}

It has been reported that there is a significantly higher frequency of circulating Th17 cells in active $\mathrm{BD}$ patients compared with the same patients in remission stages [14]. A positive correlation was noted between $C$ reactive protein (CRP), erythrocyte sedimentation rate (ESR), and the plasma IL-17 level in active BD patients [14]. Some reports showed that the peripheral blood Th17/Th1 ratio was significantly higher in patients with active BD compared with healthy controls $[17,18]$, and that in BD patients with uveitis or folliculitis, the Th17/Th1 ratio was more elevated [15,18]. Thus, they suggested that the balance of Th17 and Th1 cells plays a crucial role in the pathogenesis of $\mathrm{BD}$, especially in the pathogenesis of uveitis and folliculitis. Furthermore, the elevated expression of IL-23p19 mRNA was found in the erythema nodosum (EN)-like lesion of BD [19].

$\mathrm{Na}$ et al. [20] reported that IL-17 and IFN- $\gamma$ expressing CD4+memory T cells were significantly increased in patients with BD compared with healthy controls (HC). In addition, IL-17, IL-23, IL-12/23p 40 , and IFN- $\gamma$ in serum and supernatants were significantly elevated in active BD patients compared with HC [20]. IFN- $\gamma$-secreting Th17 cells have been found to be elevated in BD patients $[20,21]$. Thus, BD is associated with a mixture of TH1/Th17 cytokines.

Patients with BD in remission expressed low Th17 levels compared to active BD [14,20,22]. Thus, the population of Th17 cells is correlated with BD activity [16,23].

\subsection{IL-23-IL-17 Axis}

A recent study revealed that IL-23R is essential for the terminal differentiation of IL-17-producing effector T cells in vivo [24]. IL-23 was essential to maintain and to generate Th17 cells, even in the absence of TGF- $\beta$ [25] The IL-23-IL-17 axis is important for the inflammatory reaction in BD [15]. High levels of IL-17 [14,20] and IL-23 were noted in peripheral blood mononuclear cells (PBMC) from active BD patients [15]. Recombinant IL-23 stimulated the production of IL-17 in CD4+ T cells in BD patients [15]. Recent genetic surveys including GWAS identified IL-23R, IL-12RB2, and IL-10 as BD susceptibility loci $[2,3]$.

\subsection{The Suppressive Effect of IL-27 on Th17 Cell Differentiation}

IL-27 is an essential regulator of the proinflammatory T cell response. In mouse studies, IL-27 plays a negative role in Th17 cell differentiation. Wang C. et al. [26] reported a decreased level of IL-27 in active BD patients. Moreover, decreased IL-27 expression was correlated with uveitis activity in BD patients [26]. The inhibitory effect of recombinant IL-27 (rIL-27) on human Th17 cell differentiation was caused by up-regulation of the expression of interferon regulatory factor (IRF) 8 [26]. Previous studies revealed that the presence of IL-27 may limit Th17-mediated uveitis [27]. 
It was reported that the expression of IL-21 was elevated in the serum of active BD patients and this promoted Th17 differentiation [23].

\section{Th17 in Uveitis in BD}

It has been reported that IL-23, IFN- $\gamma$, and IL-17 both in the sera and aqueous humor showed a significant increase in $\mathrm{BD}$ patients with active uveitis compared with $\mathrm{BD}$ patients without active uveitis and HC [15]. In addition, increased frequencies of IFN- $\gamma$-producing and IL-17-producing T cells in BD patients with active uveitis were reported $[15,26]$. IL-17 was principally produced by CD45RO+ memory T cells. Thus, the IL23/IL17 pathway is associated with active uveitis in BD patients. It has also been reported that activated CD4+ T cells obtained from BD patients produce TNF- $\alpha$ in vitro. Jiang et al. reported a strong association of rs17375018 in the IL-23R gene with uveitis in BD [28]. Chi et al. showed that IL-12 exerted its inhibitory effect on IL17 through IFN- $\gamma$. They also showed that recombinant-IL-23 (rIL23) can promote the production of IL-17 by CD4+ T cells in BD patients [15]. Taken together, the up-regulated IL-17 levels may be associated with the intraocular inflammation of BD patients [15].

\subsection{Th17 in Skin}

A study using antibodies to IL-17A reported that an important population of IL-17+ cells infiltrate the erythema nodosum (EN)-like eruption in BD skin lesions [14]. Simizu et al. also reported that IFN- $\gamma+$ IL-17-producing cells were dominant and some of them were CD4+ cells in BD-EN [21]. Th17 cells are elevated in circulation and distribution over the skin lesions of BD. Thus, Th17 cells contribute to the pathophysiology of BD.

\subsection{Th17 in Entero-BD}

Gastrointestinal involvement is one of the important complications of BD. Emmi G. et al. [29] reported that $\mathrm{T}$ cells at the intestinal mucosal level produce a large concentration of TNF- $\alpha$, and in the early stage of $\mathrm{BD}$, Th1 and Th17 cells induce inflammation leading to mucosal damage though abnormal and long-lasting cytokine production as well as though both perforin- and Fas-Fas ligand-medicated cytotoxicity. Imamura et al. showed the infiltration of CD4+ and CD8+ T cells in intestinal lesions of $\mathrm{BD}$, along with the expression of mRNAs of proinflammatory and Th1 cytokines/chemokines [28]. In contrast, Ferrante et al. reported that mRNA and the serum level of IL-17 and IL-23 in BD patients with gastrointestinal involvement were not different from those with HC; therefore, a Th1 but not a Th17 response occurs with the gastrointestinal involvement of BD [30]. Thus, more studies are needed to address the pathogenetic role of IL-17 in entero-BD.

\subsection{Th17 in Neuro-BD}

The expression of RORC, which is the master transcription factor of Th17 cells, was reported to be increased in the cerebrospinal fluid (CSF) of patients with neuro-BD [31]. In addition, in the CSF, the Th17/Treg cell ratio was increased [31]. It was reported that there was an elevated level of IL-17 secretion in the sera of $\mathrm{BD}$ patients, and the increased expression of transcription factors for Th17 cells was detected in the CSF of BD patients with neurological involvement [31]. Geri et al. detected IL-21and IL-17A-producing T cells in the CSF, brain parenchyma inflammatory infiltrates, and intracerebral blood vessels from patients with active BD and CNS involvement [23]. The stimulation of CD4+ T cells with IL-21 increased Th17 and Th1 differentiation and decreased Treg cells [23]. On the other hand, Diresskeneli et al. [32] reported that IL-17 was not detectable in either the serum or CSF of neuro-BD patients. Thus, the pathogenetic role of IL-17 in neuro-BD remains controversial. 


\section{Polymorphisms}

It was reported that Th1- and Th17-related cytokines and signaling molecules participated in $\mathrm{BD}$ pathogenesis [33-35]. Some studies demonstrated that polymorphisms of Th17-related cytokines and receptors such as IL-17F, IL-23R, and IL-23 A were associated with BD susceptibility in Chinese and Korean populations [36-38]. STAT4 is essential for the expansion of Th17 cells activated by IL-23. Functional studies indicated that the risk of single nucleotide polymorphisms (SNPs) in the STAT4 gene involved in the pathogenesis of BD may affect the expression of STAT4 and the production of IL-17 [39]. The haplotype of IL17 A showed a positive association with the intestinal BD risk, where those of IL23R protected against disease development. The interactions of specific IL17A, IL23 Rs, and STAT4 SNPs modulate susceptibility to intestinal BD in the Korean population, suggesting the potential significance of the IL-17/23 axis in the pathogenesis of intestinal BD [40].

\section{Plasticity}

Recent studies showed that the plasticity of Th17 and Th17 cells means that they have the ability to produce Th1 (IFN- $\gamma$ ) or Th2 (IL-4)-type cytokines under inflammation [41,42]. Th17 cells can turn into IFN- $\gamma$-expressing $\mathrm{T}$ cells in mouse Th1 disease models, which are named Th1-like cells, IFN- $\gamma$-expressing Th17 cells, or Th17/Th1 cells. The expression of RORC-the master transcription factor of Th17-is not fixed in T cells, and the plasticity of Th17 cells was noted in murine models in vivo [28]; some reports have applied this conception to human diseases [43,44]. Geri et al. reported that the frequencies of both IL-17+CD4+ T cells and IFN- $\gamma+C D 4+T$ cells were elevated in the CSF compared to the PBMC in BD patients [23]. Th17 and Th1 cells may be involved at different stages in inflammation, and Th17 cells were generated more than Th1 cells during inflammation. The increase in Th17/Th1 and Th17/Treg ratios is correlated with the extent of inflammation. As in many other inflammatory diseases, in BD, plasticity exists between Th1, Th17, and Treg cells during inflammation in the peripheral circulation and at inflammatory sites [45]. The decreased levels of Th17 in remission BD compared with active BD could be explained by a conversion of Th17 cells into Treg cells. The differentiation of Tregs into Th17 cells was involved in the down-regulation of FoxP3 expression and the suppressor function. Foxp3 has been suggested to inhibit Th17 differentiation by antagonizing the ROR $\gamma \mathrm{t}$ function [46].

\section{Treatment with Cyclosporin A}

Cyclosporin A (CsA) is effective for reducing the frequency and severity of intraocular inflammation in BD. Chi et al. demonstrated that CsA has an effect on both IL-17 and IFN- $\gamma$ production in vitro and in vivo. In vitro, it was shown that CsA inhibited IL-17 production from peripheral blood mononuclear cells (PBMC) of BD patients. In vivo, the amelioration of intraocular inflammation in BD was accompanied by the suppression of both IL-17 and IFN- $\gamma$ production after CsA administration [22]. Taken together, it is suggested that the efficacy of CsA on uveitis in BD is through inhibiting of IL-17 and IFN- $\gamma$ production.

\subsection{Treatment with Antibodies to IFN- $\alpha$}

Type I IFNs including IFN- $\alpha$ could inhibit IL-17 production by PBMC. Recombinant IFN- $\alpha$ has been used to treat BD [41]. In vitro experiments showed that IFN- $\alpha$ does not directly modulate the Th1/Th17 balance in BD, but rather promotes a regulatory Th1 response through IL-10 secretion [47]. IFN- $\alpha$ activity was mediated via STAT2 phosphorylation [48]. IFN- $\alpha$ was also able to up-regulate the gene expression of IL-27-a negative regulator of Th17 cells [49].

\subsection{Treatment with Anti-TNF- $\alpha$ Therapy}

TNF- $\alpha$ has been found in BD patients [4]. Anti-TNF- $\alpha$ therapy suppresses effector T cell differentiation in $\mathrm{BD}$ patients with uveitis $[13,50]$. It was reported that the production of IL-17 by 
polarized Th17 cell lines exposed to infliximab in vitro or fresh CD4+ T cells from BD patients being treated with infliximab was reduced, and the ROR $\gamma \mathrm{t}$ in T cells was also reduced. Thus, TNF- $\alpha$ is required for TH17 differentiation in BD. CD4+ T cells exposed to anti-TNF- $\alpha$ therapy may convert into Treg cells.

Anti-TNF- $\alpha$ therapy-induced Treg cells from BD patients suppressed the activation of target $\mathrm{T}$ cells [13]. Thus, the Th17/Treg balance may be important for the pathogenesis of inflammation in $\operatorname{BD}[33,48]$.

\subsection{Treatment with Antibodies to IL-17 A}

IL-17A has an important role in acute attacks of not only eye disease but also oral ulcers, genital ulcers, and articular symptoms [14-16]. IL-17A from patients with active BD can elevate the expression of adhesion molecule mRNA. Treatment with antibodies to IL-17A suppressed the production of adhesion molecules $[14,51]$. Thus, therapeutic modalities attempting to evaluate new approaches to eliminate the overactivities of IL-17A and/or the IL-23/IL-17 pathway may clarify the pathological importance of Il-17A and Th17 cells in BD patients.

\section{Conclusions}

BD is predominated by Th1 and Th17 immune responses. Th17 cells are associated with the active inflammation of BD. Thus, Th1/Th17-type immune responses and the IL-23-IL-17 axis are important for the inflammatory reaction and have a pathologic role in BD.

Author Contributions: Yuki Nanke, Toru Yago and Shigeru Kotake analysed the references and wrote the manuscript. Conflicts of Interest: The authors declare no conflict of interest.

\section{Abbreviation}

BD

Behcet's disease

\section{References}

1. Nanke, Y.; Kotake, S.; Ogasawara, K.; Shimakawa, M.; Takasawa, S.; Ujihara, H.; Matsubara, M.; Miyanaga, Y.; Kamatani, N. Raised plasma adrenomedullin level in Behcet's disease patients. Mod. Rheumatol. 2003, 13, 139-142. [CrossRef] [PubMed]

2. Misuki, N.; Meguro, A.; Ota, M.; Ohno, S.; Shiota, T.; Kawagoe, T.; Ito, N.; Kera, J.; Okada, E.; Yatsu, K.; et al. Genome-wide association studies identify IL23R-IL12 RB 2 and IL10. Nat. Genet. 2010, 42, 703-706. [CrossRef]

3. Remers, E.F.; Cosan, F.; Kirino, Y.; Ombrello, M.J.; Abaci, N.; Satorius, C.; Le, J.M.; Yang, B.; Korman, B.D.; Cakiris, A.; et al. Genomewide association study identifies variants in the MHC class, I.; IL-10, and IL-23R-IL12 RB2 regions associated with Behcet's disease. Nat. Genet. 2010, 42, 698-702. [CrossRef] [PubMed]

4. Hamzaoui, K.; Hamzaoui, A.; Guemira, F.; Bessioud, M.; Ayed, K. Cytokine profile in Behcet's disease patients. Relationship with disease activitiy. Scand. J. Rheumatol. 2002, 31, 205-210. [CrossRef] [PubMed]

5. Ben Ahmed, M.; Houman, H.; Miled, M.; Dellagi, K.; Louzir, H. Involvement of chemokines and Th1 cytokines in the pathogenesis of mucocutaneous lesions of Behcet's disease. Arthritis Rheumatol. 2004, 50, 2291-2295. [CrossRef] [PubMed]

6. Direskeneli, H.; Fujita, H.; Akdis, C.A. Regulation of TH17 and regulatory T cells in patients with Behcet's disease. J. Allergy Clin. Immunol. 2011, 128, 665-666. [CrossRef] [PubMed]

7. Yoshimura, T.; Sonoda, K.H.; Miyazaki, Y.; Iwakura, Y.; Ishibashi, T.; Yoshimura, A.; Yoshida, H. Differential roles for IFN-gamma and IL-17 in experimental autoimmune uveoretinitis. Int. Immunol. 2008, 20, $209-214$. [CrossRef] [PubMed]

8. Yoshimura, T.; Sonoda, K.H.; Ohguro, N.; Ohsugi, Y.; Ishibashi, T.; Cua, D.J.; Kobayashi, T.; Yoshida, H.; Yoshimura, A. Involvement of Th17 cells and the effect of anti-IL-6 therapy in autoimmune uveitis. Rheumatology 2009, 48, 347-354. [CrossRef] [PubMed] 
9. Cui, Y.; Shao, H.; Lan, C.; Nian, H.; O’Brien, R.L.; Born, W.K.; Kaplan, H.J.; Sun, D. Major role of gamma delta $\mathrm{T}$ cells in the generation of IL-17+ uveitogenic T cells. J. Immunol. 2009, 183, 560-567. [CrossRef] [PubMed]

10. Oh, K.; Byoun, O.J.; Ham, D.I.; Kim, Y.S.; Lee, D.S. Invariant NKT cells regulate experimental autoimmune uveitis through inhibition of Th17 differentiation. Eur. J. Immunol. 2011, 41, 392-402. [CrossRef] [PubMed]

11. Shim, J.; Byun, H.O.; Lee, Y.D.; Lee, E.S.; Sohn, S. Interleukin-6 small interfering RNA improved the herpes simplex virus-induced systemic inflammation in vivo Behcet's disease-like mouse model. Gene. Ther. 2009, 16, 415-425. [CrossRef] [PubMed]

12. Choi, B.; Hwang, Y.; Kwon, H.J.; Lee, E.-S.; Park, K.Y.; Bang, D.; Lee, S.; Sohn, S. Tumor necrosis factor alpha small interfering RNA decreases herpes simplex virus-induced inflammation in a mouse model. J. Dermatol. Sci. 2008, 52, 87-97. [CrossRef] [PubMed]

13. Sugita, S.; Kawazoe, Y.; Imai, A.; Yamada, Y.; Horie, S.; Mochizuki, M. Inhibition of Th 17 differentiation by anti-ANF-alpha therapy in uveitis patients with Behcet'S disesase. Arthritis Res. Ther. 2012, 14, 99. [CrossRef] [PubMed]

14. Hamzaoui, K.; Bouali, E.; Ghorbel, I.; Khanfir, M.; Houman, H.; Hamzaoui, A. Expression of Th17 and ROR $\gamma \mathrm{t}$ mRNA in Behcet's disease. Med. Sci. Monit. 2011, 17, CR227-CR234. [CrossRef] [PubMed]

15. Chi, W.; Zhu, X.; Yang, P.; Liu, X.; Lin, X.; Zhou, H.; Huang, X.; Kijlstra, A. Upregulated IL-23 and IL-17 in Behcet's patients with active uveitis. Investig. Ophthalmol. Vis. Sci. 2008, 49, 3058-3064. [CrossRef] [PubMed]

16. Ekinci, N.S.; Alpsoy, E.; Karakas, A.A.; Yilmaz, S.B.; Yegin, O. IL-17A has an important role in the acute attacks of Behcet's disease. J. Investig. Dermatol. 2010, 130, 2136-2138. [CrossRef] [PubMed]

17. Cetin, E.A.; Cosan, F.; Cefle, A.; Deniz, G. IL-22-secreting Th22 and IFN- $\gamma$-secreating Th 17 cells in Behcet's disease. Mod. Rheumatol. 2014, 24, 802-807. [CrossRef] [PubMed]

18. Kim, J.; Park, J.A.; Lee, E.Y.; Lee, Y.J.; Song, Y.W.; Lee, E.B. Imbalance of Th 17 to Th 1 cells in Behcet's disease. Clin. Exp. Rheumatol. 2010, 60, S16-S19.

19. Lew, W.; Chang, J.Y.; Jung, J.Y.; Bang, D. Increased expression of interleukin-23 p19 mRNA in erythema nodosum-like of Behcet's disease. Br. J. Dermatol. 2008, 158, 505-511. [CrossRef] [PubMed]

20. Na, S.Y.; Park, M.J.; Park, S.; Lee, E.S. Up-regulation of Th 17 and related cytokines in Behcet's disease corresponding to disease activity. Clin. Exp. Rheuatol. 2013, 77, 32-40.

21. Shimizu, J.; Takai, K.; Fujiwara, N.; Arimitsu, N.; Ueda, Y.; Wakisaka, S.; Yoshikawa, H.; Kaneko, F.; Suzuki, T.; Suzuki, N. Excessive CD4 ${ }^{+}$T cells co-expessing interleukin-17 and interferon- $\gamma$ in patients with Behcet's disease. Clin. Exp. Immunol. 2011, 168, 68-74. [CrossRef] [PubMed]

22. Chi, W.; Yang, P.; Zhu, X.; Wang, Y.; Chen, L.; Huang, X.; Liu, X. Production of interleukin-17 in Behcet's disease is inhibited by cyclosporine A. Mol. Vis. 2010, 16, 880-886. [PubMed]

23. Geri, G.; Terrier, B.; Rosenzwajg, M.; Wechsler, B.; Touzot, M.; Seilhean, D.; Tran, T.; Bodaghi, B.; Musset, L.; Soumelis, V.; et al. Critical role of IL-21 in modulating $\mathrm{T}_{\mathrm{H}} 17$ and regulatory $\mathrm{T}$ cells in Behcet's disease. J. Allergy Clin. Immunol. 2011, 128, 655-664. [CrossRef] [PubMed]

24. McGeachy, M.J.; Chen, Y.; Tato, C.M.; Laurence, A.; Shaikh, B.J.; Blumenschein, W.M.; McClanahan, K.T.; O'Shea, J.J.; Cua1, D.J. The interleukin-23 receptor is essential for the terminal differentiation of interleukin 17-producing effector T helper cells in vivo. Nat. Immunol. 2009, 10, 314-324. [CrossRef] [PubMed]

25. Das, J.; Ren, G.; Zhang, L.; Roberts, A.I.; Zhao, X.; Bothwell, A.L.M.; Kaer, L.V.; Shi, Y.; Das, G. Transforming growth factor beta is dispensable for the molecular orchestration of Th17 cell differentiation. J. Exp. Med. 2009, 206, 2407-2416. [CrossRef] [PubMed]

26. Wang, C.; Tian, Y.; Ye, Z.; Kijlstra, A.; Zhou, Y.; Yang, P. Decreased interleukin 27 expression is associated with active uveitis in Behcet's disease. Arthritis Res. Ther. 2014, 16, R117. [CrossRef] [PubMed]

27. Amadi-Obi, A.; Yu, C.R.; Liu, X.; Mahdi, R.M.; Clarke, G.L.; Nussenball, R.B.; Gery, I.; Lee, Y.S.; Egwuagu, C.E. Th17 cells contribute to uveitis and scleritis and are expanded by IL-2 and inhibited by IL-27/STAT1. Nat. Med. 2007, 13, 711-718. [CrossRef] [PubMed]

28. Lee, Y.K.; Turner, H.; Maynard, C.L.; Oliver, J.A.; Chen, D.; Elson, C.O.; Weaver, C.T. Late development plasticity in the T helper 17 lineage. Immunity 2009, 141, 1014-1023.

29. Emmi, G.; Silvestri, E.; Bella, C.D.; Grassi, A.; Benagiano, M.; Cianchi, F.; Squatrito, D.; Cantarini, L.; Emmi, L.; Selmi, C.; et al. Cytotoxic Th 1 and Th 17 cells infilatrate the intestinal mucosa of Behcet patients and exhibit high levels of TNF- $\alpha$ in early phases of the disease. Medicine 2016, 49, e5516. [CrossRef] [PubMed] 
30. Ferrante, A.; Ciccia, F.; Principato, A.; Giardina, A.R.; Impastato, R.; Peralta, S.; Triolo, G. A Th 1 but not a Th17 response in present in the gastrointestinal involvement of Behcet's disease. Clin. Exp. Rheumatol. 2010, 60, S27-S30.

31. Hamzaoui, K.; Borhani haghighia, A.; Ghorbel, L.B.; Houman, H. RORC and Foxp3 axis in cerebrospinal fluid of patients with neuro-Behcet's disease. J. Neuroimmunol. 2011, 233, 249-253. [CrossRef] [PubMed]

32. Sarhan-direskeneli, G.; Yentur, S.P.; Akman-Demir, G.; Isik, N.; Serdaroglu, P. Cytokines and chemokines in neuro-Behcet's disease compared to multiple sclerosis and other nerurological disease. J. Neuroimmunol. 2003, 145, 127-134. [CrossRef]

33. Shimizu, J.; Izumi, T.; Arimitsu, N.; Fujiwara, Y.; Ueda, S.; Wakisaka, H.; Yoshikawa, H.; Kaneko, F.; Suzuki, T.; Takai, K.; et al. Skewed TGF $\beta$ /smad signaling pathway in T cells in patients with Behcet's disease. Clin. Exp. Rheumaol. 2012, 30, S35-S39.

34. Shaharam, F.; Nikoopour, E.; Rezaei, N.; Saeedfar, K.; Ziaei, N.; Davatchi, F.; Amirzargar, A. Association of interleukin-2, interleukin-4 and transforming growth factor-beta gene polymorphisms with Behcet's disease. Clin. Exp. Rheumaol. 2011, 30, S28-S31.

35. Zhang, Y.J.; Xu, W.D.; Duan, Z.H.; Liu, S.S.; Pan, H.F.; Ye, D.Q. Lack of association between CTLA 4+49A/G and $-318 \mathrm{C} / \mathrm{T}$ polymorphisms and Behcet's disease risk: A meta-analysis. Clin. Exp. Rheumaol. 2012, 30, S46-S50.

36. Jiang, Z.; Yang, P.; Hou, S.; Du, L.; Xie, L.; Zhou, H.; Kijlstra, A. IL-23R gene confers susceptibility to Behcet's disease in a Chinease Han population. Ann. Rheumatol. Dis. 2010, 69, 1325-1328. [CrossRef] [PubMed]

37. Jang, W.C.; Nam, Y.F.; Ahn, Y.C.; Lee, S.H.; Park, S.H.; Choe, J.Y.; Lee, S.S.; Kim, S. Interleukin-17F gene polymorphisms in Korean patients with Behcet's disease. Rheumatol. Int. 2008, 29, 173-178. [CrossRef] [PubMed]

38. Hou, S.; Liao, D.; Zhang, J.; Fang, J.; Chen, L.; Qi, J.; Zhang, Q.; Liu, Y.; Bai, L.; Zhou, Y.; et al. Genetic variation of IL17F and Il23A show associations with Behcet's disease and vogt-koyanagi-harada syndrome. Am. Ophthalmol. 2015, 122, 518-523. [CrossRef] [PubMed]

39. Hou, S.; Yang, Z.; Du, L.; Jiang, Z.; Shu, Q.; Chen, Y.; Li, F.; Zhou, Q.; Ohno, S.; Chen, R.; et al. Identification of a susceptibility locus in STAT4 for Behcet's disease in Han Chinese in a genome-wide association study. Arthritis Rheumatol. 2012, 64, 4104-4113. [CrossRef] [PubMed]

40. Kim, E.S.; Kim, S.W.; Moon, C.M.; Park, J.J.; Kim, T.L.; Kim, W.H.; Cheon, J.H. Interractions between IL-17A, Il23R, and STAT4 polymorphisms confer susceptibility to interstinal Behcet's disease in Korean population. Life Sci. 2012, 90, 740-745. [CrossRef] [PubMed]

41. Deuter, C.M.; Zierhat, M.; Mohle, A.; Vonthein, R.; Stobiger, N.; Kotter, I. Long-term remission after cessation of interferon-a treatment in patients with severe uveitis due to Behcet's disease. Arthritis Rheumatol. 2010, 62, 2796-2805. [CrossRef] [PubMed]

42. Harrington, L.E.; Hatton, R.D.; Mangan, P.R.; Turner, H.; Murphy, T.L.; Murphy, K.M.; Weaver, C.T. Interleukin 17-producing CD4+ effector T cells develop via a lineage distinct from the $\mathrm{T}$ helper type 1 and 2 lineages. Nat. Immunol. 2005, 6, 1123-1132. [CrossRef] [PubMed]

43. Nistala, K.; Adams, S.; Cambrook, H.; Ursu, S.; Olivito, B.; Jager, W.D.; Evans, J.G.; Cimaz, R.; Bajaj-Elliottf, M.; Wedderburn, L.R. Th17 plasticity in human autoimmune arthritis is driven by the inflammatory environment. Proc. Natl. Acad. Sci. USA 2010, 107, 1451-1456. [CrossRef] [PubMed]

44. Cosmi, L.; Cimaz, R.; Maggi, L.; Santarlasci, V.; Capone, M.; Borriello, F.; Frosali, F.; Querci, V.; Simonini, G.; Barra, G.; et al. Evidence of the transient nature of the Th17 phenotype of CD4+CD161+ T cells in the synovial fluid of patients with juvenile idiopathic arthritis. Arthritis Rheumatol. 2011, 63, 2504-2515. [CrossRef] [PubMed]

45. Hamzaoui, K. Th17 cells in Behcet's disease: A new immunoregulaory axis. Clin. Exp. Rheumatol. 2011, 67, S71-S76.

46. Zhou, L.; Lopes, J.E.; Mark, M.W.; Lvanov, I.I.; Min, R.; Victora, G.D.; Shen, Y.; Du, J.; Rubtsov, Y.P.; Rudensky, A.Y.; et al. TGF-beta induced Foxp3 inhibits $\mathrm{T}_{\mathrm{H}} 17$ cell differentiation by antagonizing RORgammat function. Nature 2008, 453, 236-240. [CrossRef] [PubMed]

47. Touzot, M.; Cacoub, P.; Bodaghi, B.; Soumelis, V.; Saadoun, D. INF- $\alpha$ induces IL-10 production and tilt the balance between Th1 and Th17 in Behcet's disaseas. Autoimmun. Rev. 2015, 14, 370-375. [CrossRef] [PubMed] 
48. Liu, X.; Yang, P.; Wang, C.; Li, F.; Kijlstra, A. IFN-a blocks IL-17 production by peripheral blood mononuclear cells in Behcet's disease. Rheumatology 2011, 50, 293-298. [CrossRef] [PubMed]

49. Pirhonen, J.; Siren, J.; Julkunen, I.; Matikainen, S. IFN-alpha regulates Toll-like receptor-mediated IL-27 gene expression in human macrophages. J. Leukoc. Biol. 2007, 82, 1185-1192. [CrossRef] [PubMed]

50. Ohno, S.; Nakamura, S.; Hori, S.; Shimakawa, M.; Kawashima, H.; Mochizuki, M.; Sugita, S.; Ueno, S.; Yoshizake, K.; Inaba, G. Efficacy, safety, and pharmacokinetics of multiple administration of infliximab in Behcet's disease with refractory uveoretinitis. J. Rheumatol. 2004, 31, 1362-1368. [PubMed]

51. Zhang, R.; Qian, J.; Guo, J.; Yuan, Y.F.; Xue, K. Supression of experimental autoimmune uveoretinitis by anti-IL-17 antibody. Curr. Eye Res. 2009, 34, 297-303. [CrossRef] [PubMed]

(C) 2017 by the authors. Licensee MDPI, Basel, Switzerland. This article is an open access article distributed under the terms and conditions of the Creative Commons Attribution (CC BY) license (http://creativecommons.org/licenses/by/4.0/). 